\title{
Designing a Balanced Scorecard to Measure a Bank's Performance: A Case Study
}

\author{
Sabah M. Al-Najjar (Corresponding author) \\ Department of Business Management, College of Administration and Economics \\ University of Baghdad, Baghdad, Iraq
}

Tel: 964-7709-726-485Ｅ-mail: sabanajar@yahoo.com

Khawla H. Kalaf

Higher Institute for Accounting and Financial Studies, Department of Financial Studies

University of Baghdad, Baghdad, Iraq

Tel: 964-7702-591-526Ｅ-mail: h_khawla@yahoo.com

\author{
Received: April 19, 2012 \\ Accepted: May 9, $2012 \quad$ Published: July 15, 2012 \\ doi:10.5430/ijba.v3n4p44 \\ URL: http://dx.doi.org/10.5430/ijba.v3n4p44
}

\begin{abstract}
Performance measurement systems play a key role in evaluating the strategic performance of an organization, but many managers agree that their evaluation systems do not adequately fulfill this function. Hence, in recent years a shift towards the Balanced Scorecard (BSC) has emerged as a managerial approach to evaluate the strategic performance of the organization. The purpose of this study is to contribute to the understanding of how BSC is developed and applied in evaluating the performance of a Large Local Bank (LLB) in Iraq. Using the concepts of Kaplan and Norton, and the data made available from the bank, a BSC was derived to measure the performance of the bank between 2006-2009. The analysis assisted the cause-effect relationships between the non-financial, and the financial dimensions of the BSC. Due to lack of research work, in this area, in the banking sector in Iraq, this study shall contribute to the knowledge on how banks in Iraq may apply the BSC to evaluate their performance, and how they might turn strategic vision into potential performance. The authors proposed some future research needs required in this area. The use of the BSC developed here is limited to the bank studied; however, the approach could trigger off reflections among policy makers and other banks to start using the BSC.
\end{abstract}

Keywords: Balanced scorecard, Performance management, Performance evaluation, BSC methodology, Iraq

\section{Introduction}

In the past few decades, performance measurement has become a hot topic, and has witnessed continuous development and modifications by academicians and practitioners. The interest in this topic is triggered by the growing criticism of financial measures use in the performance management systems, therefore, researchers have been trying to arrive at efficient and effective approaches to measure performance. Financial measures of performance were criticized by many authors (Singh \& Kumar, 2007) for: being short term oriented, considering past performance, being non consistent with current business's environment, focusing on tangible assets, lacking predictive power, reinforcing functional silos, and being irrelevant for all levels in the organizations.

Through field observations and interviews with directors in the banking sector in Baghdad (capitol of Iraq), the authors arrived at three important facts. Firstly, performance measurement in the banking sector in Iraq does not attract many researchers, secondly, the BSC is an approach that is not known within the banking sector in Iraq, and thirdly, the banks are still using primitive performance evaluation systems such as annual, quarterly and monthly reports. More specifically, we found that the LLB (with over 100 branches throughout Iraq) depends on financial measures such as: ROI, Liquidity Ratio, Financial Leverage Ratio, Profitability Ratio, Credit Ratio, etc. to judge its performance.

At the research level, we did not encounter any research work that deals with the implementation of the BSC to measure the performance of banks in Iraq, and to establish links between their strategic vision and performance objectives.

The authors believe that with the openness of Iraq to the world and foreign investors after 2003, the banking sector 
should start adopting holistic performance measurement systems such as the BSC to demonstrate to stakeholders that this sector is turning to exploit financial and non-financial measures to provide investors with performance information. Therefore, a research work of this type is significant and worthy of investigation within the context of the banking sector in Iraq. We expect that this work shall increase our understanding in this topic, bridge the gap of knowledge in this area, and attract the attention of the authorities in the Central Bank of Iraq to consider the use of the BSC as a measurement and strategic performance tool in the banking sector in Iraq.

\section{Strategy Implementation, Performance, and BSC}

To achieve a competitive edge, and to retain customers; organizations should be innovative to fulfill the ever changing needs of their customers. Being innovative leads to customers' satisfaction which in turn strengthens the financial position of the organization (Ahmad et. al., 2010). Therefore, organizations should develop sound strategies to maintain strong financial positions. Evans (2005) mentioned that strategies may be very well drawn and presented, but the problem is that strategy is not very well communicated to people involved in the execution process. Charan \& Colvin (1999) pointed that although strategy execution is everyone's business in the organization, the final result is poor strategy execution in many organizations. Top management formulates strategy, but the execution is a bottom up process.

According to Anand (2004) four barriers are responsible for strategy implementation:

- Vision Barrier: Few people in the organization understand the strategy of their organization.

- People Barrier: The objectives of most workers are not linked to the organization's strategy.

- Resource Barrier: Misallocation of time, energy, and money to processes that are critical to the organization.

- Management Barrier: Management allocates little time to strategy, and much time to short-term tactical decision-making.

Kaplan and Norton (2000) argued that most companies fail to execute strategies, and that:

- Only $5 \%$ of the workforce understands their company's strategy.

- Only $25 \%$ of managers have incentives linked to strategy.

- $60 \%$ of organizations don't link budgets to strategy.

- $86 \%$ of executive teams spend less than one hour per month discussing strategy.

With respect to performance measurement, the literature indicates that most operational and control systems are designed around financial measures and targets. Namazi \& Abhari (2010) mention that prior to 1980's, organizations used financial measures (ROI, net profit, return on equity etc.) to evaluate their performance, however it is very well known that financial measures are good, only, in the short term.

The emphasis placed by most companies on financial measures creates a gap between strategy development and implementation. Therefore, it is imperative to communicate the strategy to everyone in the organization in an understandable language. If strategy is well expressed in terms of measurements and targets, then employees will understand their roles and what is expected from them. This will finally lead to better strategy execution and enhanced performance (Kaplan \& Norton, 1996).

The issues of poor strategic implementation, and the reliance on financial measures only to judge the strategic performance of the organization motivated Kaplan and Norton (1992) to propose the BSC (in a series of articles) as a tool to link performance measures by looking at the business's strategic vision from four different perspectives: Financial, Customer, Internal Processes, and Learning and Growth. The BSC is intended to document a strategic logic in terms of cause and effect relationships between the current activities of an organization and its long-term success.

The following is a description of the BSC perspectives based on Kaplan and Norton (1992, 1996):

Financial Perspective: Financial measures convey the economic consequences for the actions already taken by the organization, and focus on the profitability related measures on which the shareholders verify the profitability of their investment. Therefore, under this perspective managers are required to generate measures that answer the following question: "To succeed financially, how should we appear to our shareholders?" Kaplan and Norton acknowledge the need for traditional financial data. The accurate and timely financial data are necessary for the efficient and smooth direction of the organization. The provision of the right and timely financial data to the right person in the organization helps much in the process of making the right decision in the right moment. Under this perspective the most common performance measures incorporated are: ROI, Cash Flow, Net Operating Income, Revenue Growth, etc.

Customer Perspective: This perspective provides a view on how customers perceive the organization. The customer 
perspective should be considered the central element of any business strategy that provide the unique mix of products, price, relationship, and image that the company offers to its customers. In this perspective the organization should demonstrate how it differentiates itself from the competitors by retaining, attracting, and sustaining relationships with its targeted customers. Therefore, managers are required to generate measures to answer the following question: "To achieve our vision, how should we appear to our customers?" Typical measures used under this perspective are: customer satisfaction, customer complaints, customer lost/won, sales from new product, etc.

Internal Business Processes Perspective: Internal business processes provide the organization with the means by which performance expectations may be accomplished. This perspective refers to the internal business processes of the organization and, therefore, managers are required to provide measures that answer the following question: "To satisfy our customers and shareholders, what business processes must we excel at?" The central theme of this perspective is the results of the internal business processes which lead to financial success and satisfied customers. Typically the measures of this perspective are based on producing goods and services in the most efficient and effective methods. Commonly used measures for this perspective are: cost of quality, cost of non-conformance, process innovation, time savings etc.

Learning and Growth Perspective: Under this perspective managers must identify measures to answer the following question: "To achieve our vision, how will we sustain our ability to change and improve?" Actually, this perspective is related to the employees of the organization, and it measures the extent to which the organization exerts efforts to provide its employees with opportunities to grow and learn in their domain. Kaplan and Norton acknowledge that the learning and growth measures are the most difficult to select; therefore they suggest the following measures as examples: employee empowerment, employee motivation, employee capabilities, and information systems capabilities.

The early BSC model, we described above, consisted of simple tables including four parts, each part is referred to as a perspective or a dimension. These perspectives are supposed to create a balance between short-term and long-term objectives. Newing (1995) stated that by combining measuring and thinking by the four perspectives managers can prevent making improvements in one area at the expense of another area. According to the author, the BSC forces managers to focus on non-financial measures which impact on the long-term profitability of the organization. Kaplan and Norton (1992) acknowledged that the format of the BSC depends on the needs of the organization.

In the original version of the BSC model (Figure 1), goals and measures were the only two parameters used by the scorecard (Scherer, 2002). The major issue facing an organization in developing a BSC of this type is how to choose the measures that are explicitly linked to its strategy? The underlying assumption here is that strategy is widely communicated and accepted organization wide. Another important problem in this model is how to choose the correct measures? If managers believe that the chosen measures are not well, then they will not have confidence in the information that these measures supply.

In the mid of the 1990s, Kaplan and Norton (1996) promoted a new version of the BSC to alleviate the problems of the early model. This version, presented in Figure 2, contains four perspectives, too. Each perspective, now, consists of four parameters: goals, objectives, targets, and initiatives. It, also, depends on four processes that bind short-term activities to long-term objectives (Figure 3).

In this new model, the selection of the measures is done on the basis of a set of "strategic objectives" plotted on a "strategic linkage model" or "strategy map". The strategic objectives are spread among the four perspectives: Financial, Customer, Internal Processes, and Learning and Growth. However, the design of the BSC becomes less abstract. Within each perspective, managers are supposed to identify five or six goals. By plotting causal links, managers can delineate the links between these goals. When a reasonable agreement is achieved on the objectives, and how they inter-link, then a BSC can be devised by identifying suitable measures for each objective. This methodology provides managers with greater contextual justification for choosing the measures within each perspective, and is easier for them to work with.

Kaplan and Norton (1996) argue that this version could be used as a strategic management system which supports the aforementioned perspectives. The elements of this strategic management system are: Translating the Vision, Communicating and Linking, Business Planning, and Feedback and Learning.

- Translating the Vision: Kaplan and Norton suggest that lofty statements such as "becoming the number one supplier" are difficult to translate into operational measures that bear meaning to all the people in the organization. However, by relying on measurement, the scorecard shall force management to arrive at an agreement on the metrics they will use to operationalize their vision.

- Communicating and Linking: The implementation of strategy starts with communicating it up and down the organizational chart and educating personnel who will execute the strategy. By passing strategy across the organization, objectives and measures can be translated into objectives and measures pertaining to particular groups. 
Relating these targets to individual's performance, a "personal scorecard" is achieved, in this way employees can understand how their performance can support the organizational strategy.

- Business Planning: Kaplan and Norton indicate that most organizations have separate units for strategic planning and budgeting. However, in practice these two functions rarely coincide on achieving the organization's strategy. The idea of creating a balanced scorecard obliges companies to integrate these two functions to ensure that budgets do indeed support strategic goals. By arriving at an agreement on the performance measures for the four perspectives, the company can identify the most influential drivers of the outcomes desired, and then setting milestones to measure the progress achieved with these drivers.

- Feedback and Learning: The existing feedback and review processes of a company focus on whether the budgeted financial goals of the company, or its units, or its employees have been met. Using the balanced scorecard as a management system, the company can monitor and control the short-term results from the other three perspectives: customers, internal business processes, and learning and growth. Thus, the company can review and evaluate its strategy according to recent performance. The scorecard, therefore, aids the company in modifying its strategies to reflect real-time learning.

According to Ashton (1998) the BSC can be used as:

- A framework for implementing corporate strategy.

- A tool for linking business, team and individual objectives and rewards to strategic goals.

- An effective tool for implementation of change management.

- A good match with the organization's deviation from a command and control culture to empowerment and coaching culture.

- A way to understand the drivers of business success.

- An identifier of "cause-and-effect" relationships across operations.

- A dynamic communication and a feedback tool.

As many organizations started to depend on intangible assets to measure performance, the scorecards are becoming a useful approach for performance evaluation (Kaplan \& Norton, 1993). Silk (1998) highlighted that a US survey found that $60 \%$ of Fortune 1000 firms have implemented the BSC. Since 1996, the interest in BSC has grown tremendously among academicians and practitioners, and its implementation impressed many organizations around the world (Zaman, 2004). As cited by Singh \& Kumar (2007), there is great evidence which supports the application of the BSC in different business sectors such as: FHC Corporation, Apple Computer Company, Advanced Micro Devices, DHC Chemical Division, Natwest Bank, Chemical Bank, Mobil's US Marketing and Refining Division, and Rockwater Engineering. We believe that this area is fertile and shall continue to attract practitioners, researchers, and academicians in the future.

\section{Literature Review}

Many academics and executives were attracted by the works of Kaplan and Norton, and have attempted to study the BSC concept and work to perfection it on the theoretical and practical levels. The BSC gradually gained popularity in the USA, Europe, Australia, and Latin America (Janota, 2008). The application of the BSC spread among different business sectors including the banking sector.

Tapanya S. (2004) examined the factors which affect the performance management systems in a highly uncertain and rapidly changing environment through the application of the BSC approach. Through several consecutive qualitative and quantitative studies in the Thai banking industry post the 1997 financial crisis, the author concludes that the institutional forces play a decisive role in the selection of the performance measurement system regardless of the strategic orientation and/ or the firm's ownership. Pandy (2005) reported the results of a simulated exercise where a group of senior managers (attending an educational program) of a large bank developed a BSC made for their bank. Guided by the author, this experiment demonstrated that the achievement of strategic objectives is highly driven by the internal process improvement and that the non-financial variables surpassed the financial variables. Harold (2006) applied the BSC to develop a comprehensive performance measurement and a management tool for the IT in the banking sector in India. The author clarified how a cascade of balanced scoreboards can be useful in the technology effectiveness of commercial banks in India to guarantee better performance management. Huang and Lin (2006) examined the performance system of five commercial banks in China. Through investigations and evaluations of the current performance systems of the sample banks, the authors were able to design a new performance evaluation system based on the BSC. Chwan-Yi and Lin (2009) attempted to develop an integrated framework by merging the concepts of the BSC and the Data 
Envelopment Analysis (DEA). An auto company and a commercial bank were selected as targets for empirical investigations. The study revealed that the synergy of the BSC and the DEA translates the appropriate performance indices into managerial implications. Zhang and $\mathrm{Li}$ (2009) believe that performance management is an important aspect of banking business management. In their study they proposed the BSC as a tool to improve the performance of commercial banks in China. The authors proposed a mechanism and a strategy for application along with the limitations of the BSC. Ahmed et al. (2011) conducted a study in which they surveyed a sample of 27 banks in Pakistan to identify the measures that are used by the sample banks to evaluate their performance according to the four perspectives of the BSC. The authors reported that all the banks surveyed used measures that correspond to the BSC approach to evaluate their performance, however, the significance of the measures varied among the sample studied. Fakhri et al. (2011) attempted to explore the usefulness of a multi-perspective performance measures in the banking sector in Libya. Through an extensive literature review, the authors identified some performance measures and have investigated the impact of five organizational individualities on these measures. Based on a survey in a sample of 55 banks in Libya, the study reported that most banks place their emphasis on financial measures as a first step to evaluate performance, however, many of the banks surveyed tended to implement customer related measures and other non financial measures such as learning and employee growth.

Apart from the banking sector, many researchers were impressed by the BSC. Bernroider et al. (2003) attempted to use the BSC approach as a tool for strategic IT-Controlling within the context of e-Business development in two beverage producing companies in Austria. The authors followed a case study methodology where the BSC was calculated using 2.5 years data. Management of the two companies considered the results of the study as adequate for supervising the e-Business environment and the associated strategic goals. Zaman (2004) investigated the current state of BSC use in Australian corporations. The author surveyed the top 50 Australian companies. The survey results revealed that only $33 \%$ of companies use the BSC and that $25 \%$ are planning to implement it in the future. The author argues that Australian companies are at the edge of adopting a strategic posture or intention to implement the BSC in the near future. Yek et al. (2007) studied the use of the BSC as a strategic management system to improve the performance quality of the Vocational Educational and Training (VET) in Singapore. This work attempted to explore and improve the understanding of quality and performance using the BSC approach. The authors claim that the BSC can be adopted as an effective quality and performance management system in a VET institution with appropriate adaptations. Greiling (2010) performed an explorative empirical study on a sample of 20 non-profit organizations in the social services sector in Germany. The purpose of the study was to investigate the BSC's implementation in terms of implementation levels, perspectives, challenges and impediments, etc. The author reported that the BSC was still used as a measurement instrument and not as a management tool in the organizations studied. Al Sawalqa et al. (2011) analyzed the implementation state of the balanced scorecard among industrial companies in Jordan. The authors surveyed 168 companies to obtain an insight on the level of BSC implementation. The study showed that $35.1 \%$ of the surveyed companies applied BSC, while $30 \%$ were considering or implementing the BSC approach. In a study conducted by Kollberg and Elg (2010), the authors attempted to identify the major characteristics of the BSC application in health care organizations in Sweden. The authors used a case study approach where they focused on different managerial levels in a hierarchical branch in three health care organizations that used the BSC. The analysis revealed that the BSC is used as a tool for enhancing internal capabilities and organizational development. More specifically, the authors reported that management and employees used the BSC as a tool in discussions, information diffusion, and knowledge creation.

Although not exhaustive, the above literature review demonstrates that the BSC approach had its chance of widespread applications in different countries and business sectors.

\section{The Research Problem}

The literature presents a strong interest on evaluating banks' performance by the BSC approach. However, the BSC, as a performance evaluation tool, did not find its way to the Iraqi business sector in general and to the banking sector, in specific. The authors did not encounter any research work mainstreamed to the BSC application in the banking sector in Iraq. In addition, the performance measurement used in the LLB is still based on financial measures, and monthly or annual reports. Although the LLB administration is not aware of it, the dependence on financial measures is misleading because it does not provide a holistic view about how the bank is doing on the internal processes, customer, and learning and growth perspectives. Therefore this study shall address the problem of developing a BSC model to measure (for the first time) the performance of the LLB. The performance results can benefit the bank studied, the stakeholders, and the financial sector analysts.

\section{Purpose and Research Methodology}

This research work aims to: 
- contribute to the BSC literature,

- encourage further research on BSC in Iraq,

- address the limitations of the present performance measurement applied in the LLB,

- increase our understanding about how the BSC may be developed and applied within the context of the banking sector in Iraq,

- and bridging the gap of knowledge on this subject in the banking sector in Iraq.

In this research the authors followed a case study approach. Relevant data were made available by the bank studied for four years (2006-2009). Data were collected directly from the bank's financial statements, monthly, quarterly, and annual reports. For confidentiality purposes the name of the bank is referred to by LLB, the years were altered, and no data from the bank's financial statements shall be declared here.

\section{Data Analysis and BSC Development}

The following steps were used to develop the BSC for the LLB:

First: Using the concept of the strategic map, the authors worked with the bank's administrators to develop a cause-effect relationship to link the bank's objectives to its strategic goals in an effort to select the measures pertaining to each of the four BSC perspectives. Five measures for each perspective were chosen as follows:

Financial perspective: Liquidity Ratio, Return on Investment, Return on Equity, Profit Margin, and Leverage Ratio.

Internal Processes Perspective: Productivity Growth, Growth of Banking Services, Credit Growth, Growth in Software Applications, and Front Office Employees.

Customer Perspective: Customer Satisfaction, Customers' Growth, Growth of Current Accounts, Growth of Saving Accounts, and Growth of Safety Deposits.

Learning and Growth: Employee Productivity, Employee Turnover Rate, Growth of the Bank's Branches, Employee Participation in Development Programs, and the Number of Employees Using IT in their work.

Second: Using the data available about the LLB performance from 2006-2009, the authors and the LLB administration were able to identify the BSC's objectives, measures, and targets for the four perspectives as they appear in Table (1).

Third: A performance scale was identified for each measure, and 50 score points were divided on the elements of each scale. The total scores in the BSC developed are therefore 1000 (20 measures x 50 points, or 250 points/perspective). Table (2) presents the measures, the scales and the scores breakdown for each measure within perspectives.

Fourth: The LLB performance is measured for the four years of study according to the scales and scores developed in step 3. The last four columns of Table (2) present the scores assigned to each measure from 2006-2009. Table (2) also shows the perspective subtotal/year, while the last row of the table presents the total score/year for all the perspectives.

\section{Findings}

The analysis reveals that the LLB performance measured by the BSC was $470,430,470$, and 580 for the years 2006-2009 respectively. Converting these scores on a $100 \%$ scale yields: $47 \%, 43 \%, 47 \%$, and $58 \%$ for the same years. It seems evident that the LLB performance was weak during the first three years of study, and fair during 2009. In general the annual average score achieved by the bank was 488 which indicates a weak performance. With respect to performance on individual perspectives, we observe from Table (2) that the scores achieved on the financial perspective improved steadily from 2006-2009 with an average annual growth rate of approximately $40 \%$. This finding coincides with the bank's concentration on the financial performance as a measure of performance. The internal processes perspective does not reveal significant improvements; the average annual growth rate was about $2 \%$. In fact the LLB performance was hurt severely on this perspective. We notice that the growth of banking services, the credit growth, and the growth on software applications measures scored zero during the third year. The LLB scores on the customer perspective were the worst. The average annual growth rate was $0 \%$ during the years of study. The customers' growth measure scored zero during these years, the reason was that customers were skeptical about the security conditions in Iraq, so some customers withdrew their money from the bank, while others found that the bank was the safest place to keep their money during unstable security conditions. Finally, the learning and growth perspective was better than the customer perspective; its average annual growth rate was about $3 \%$. Most of the measures in this perspective scored 20 or less out of 50. In specific, the growth of the bank's branches scored zero from 2006-2009, and this is due to the unstable security conditions which prevented the bank from opening new branches. 


\section{Conclusions}

This research work may be viewed as part of a diverse investigation of the usage of many performance evaluation approaches developed in the past few decades. It can, also, provide guidelines to organizations when they consider methods of performance evaluation. The purpose of this study was to increase our understanding on how the BSC approach may be developed and applied to measure the performance in the banking sector in Iraq. This study has constructed a BSC model (including 20 measures) that was used to measure the LLB performance. Despite the fact that the results of the performance of the LLB look dim, we should not blame the bank for that for two reasons. Firstly, the security condition was not in favor of the LLB, and secondly, the LLB is not aware of the BSC as a performance tool. Although the LLB did not use this approach in the past, this study has highlighted the importance of viewing performance from other perspectives in addition to the financial perspective. The bank's administration realized the importance of this tool as a strategic and valuable performance management system, and has expressed its interest and willingness to learn this approach and to apply it in the future. The successful application of the BSC does not come from a vacuum; rather top management of the bank should demonstrate its commitment to the adoption of the BSC. Future researches in the banking sector in Iraq are needed in this domain, and should focus on studying the contingent factors that facilitate or impede the implementation of the BSC such as: organizational culture, organizational structure, private vs. public organizations, environment, and technology. More studies are, also, needed to identify the relevant measures of the BSC for the banking sector. The results of this work have many implications on the authorities of the Central Bank of Iraq and policy makers in the financial sector in terms of the diffusion of the BSC as a systematic approach to performance evaluation. We expect that with the increased demands from stakeholders, financial sector analysts, educators, and practitioners the BSC shall be widely used in the banking sector in Iraq shortly.

\section{References}

Ahmad, Z., Ahmad, Z., Ahmad, I., \& Nawas, M. (2010). Balanced Scorecard: Is it a Spontaneous Performance Measurement Tool? Interdisciplinary Journal of Contemporary Research in Business, 2(2), 100-107.

Ahmed, Z., Bowra, Z., Ahmad, I., Nawaz, M., \& Khan, M. (2011). Performance Measures Used by the Commercial Banks in Pakistan within the Four Perspectives of Balanced Scorecard. Journal of Money, Investment and Banking, (21), $12-20$

Al Sawalqa, F., Holloway, D., \& Alam, M. (2011). Balanced Scorecard Implementation in Jordan: An Initial Analysis. International Journal of Electronic Business Management, 3(9), 196-210.

Anand, S. (2004). Achieving Breakthrough Performance Using the Balanced Scorecard. IBA Bulletin, 12(26), 28-31.

Ashton, C. (1998). Balanced Scorecard Benefits NatWest Bank. International Journal of Retail \& Distribution Management, 26(10), 400-401.

Bernroider, E., Hampel, A., \& Sumper A. (2003). An Application of the Balanced Scorecard as a Strategic IT-Controlling. Proceedings of the Third International Conference on Electronic Business. (ICEB), pp. 42-44, Singapore, December.

Charan, R., \& Colvin, G. (1999). Why CEOs Fail? Fortune, June, 21.

Chwan-Yi, C., \& Lin, B. (2009). An Integration of Balanced Scorecards and Data Envelopment Analysis for Firm's Benchmarking Management. Total Quality Management, 11(20), 1153-1172.

Evans, N. (2005). Assessing the Balanced Scorecard as a Management Tool for Hotels. International Journal of Contemporary Hospitality Management, 5(17), 376-390.

Fakhri, G., Menacere, K., \& Pegum, R. (2011). Organizational Specificities that affect the Use of Corporate Performance Measurements Process in the Banking Sector. Journal of Performance Management. 3(23), 5-23.

Greiling, D. (2010). Balanced Scorecard Implementation in German non-profit Organizations. International Journal of Productivity and Performance Management, 6(59), 534-554.

Harold, L. (2006). Performance Measurement and Management of Technology in Indian Banking: New Approaches. Contributors, I, Bank net India, (5), 6-18.

Huang, H., \& Lin, X. (2006). From Strategy to Action: The Balanced Scorecard for Commercial Banks. Journal of Beijing Institute of Technology, (6).

Janota, R. M. (2008). The Balanced Scorecard in a Pharmaceutical Company. PhD Thesis, Instituto Superior de Ciências do Trabalho e da Empresa, 12.

Kaplan, R. S., \& Norton, D. P. (1993). Putting the Balanced Scorecard to Work. Harvard Business Review, September-October, 134-147.

Kaplan, R. S., \& Norton, D. P. (1996). Balanced Scorecard: Translating Strategy into Action. Harvard Business School 
Press.

Kaplan, R. S., \& Norton, D. P. (2000). The Strategy-Focused Organization: How Balanced Scorecard Companies Thrive in the New Business Environment. Boston: Harvard Business School Press.

Kaplan, R.S., \& Norton, D. P. (1992). The balanced scorecard-Measures That Drive Performance. Harvard Business Review, 1(70), 71-79.

Kollberg, B., \& Elg, M. (2010). The Practice of the Balanced Scorecard in Health Care Services. International Journal of Productivity and Performance Management, 5(60), 427-445.

Namazi, M., \& Abhari, H. (2010). An Investigation of the Balanced- Scorecard's Applications for Performance Measurement of the Firms Accepted in the Tehran Securities Exchange Market. Journal of Applied Sciences Research, 6(8), 943-955.

Newing, R. (1995). Wake up to the balanced scorecard! Management Accounting, March, 22-23.

Pandy, I. M. (2005). Balanced Scorecard: Myth and Reality. Interface, 1(30), 51-66.

Scherer, D. (2002). Balanced Scorecard Overview. Core Paradigm, June, 1-5.

Silk, S. (1998). Automating the Balanced Scorecard. Management Accounting, 79(11), 38-40.

Singh, M., \& Kumar, S. (2007). Balanced Scorecard Implementations Global and Indian Experiences, Indian Studies Management Journal, (11), 21-39.

Tapanya, S. (2004). Examining the Factors which Influence Performance Measurement Management in the Thai Banking Industry: An Application of the Balanced Scorecard Framework. PhD. Thesis, Murdoch University.

Yek, T. M., Penney, D., \& Seow, A. (2007). Using Balanced Scorecard (BSC) to Improve Quality and Performance of Vocational Education and Training (VET): A Case Study in Singapore. AARE 2007 Conference, November 25 - 29: Fremantle, Australia.

Zaman, M. (2004). An Investigation into Balanced Scorecard Implementation in Australian Companies. IRMA Conference, May 23-26, New Orleans, Louisiana, USA.

Zhang, Y., \& Li, L. (2009). Study on Balanced Scorecard of Commercial Bank in Performance Management System. Proceedings of the 2009 International Symposium on Web Information Systems and Applications (WISA'09) Nanchang, P. R. China, May 22-24, 206-209.

Table 1. Balanced scorecard objectives, measures, and targets

\begin{tabular}{|c|c|c|c|}
\hline & Objectives & Measures & Target \\
\hline 㞼 & $\begin{array}{l}\text { - Survival } \\
\text { - Growth } \\
\text { - Stakeholder Satisfaction } \\
\text { - Revenue Development }\end{array}$ & $\begin{array}{l}\text { - Liquidity Ratio } \\
\text { - ROI } \\
\text { - ROE } \\
\text { - Profit Margin } \\
\text { - Leverage Ratio }\end{array}$ & $\begin{array}{l}30 \% \\
15 \% \\
400 \% \\
\$ 200000000 \\
100 \%-250 \%\end{array}$ \\
\hline 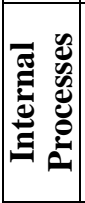 & $\begin{array}{l}\text { - Increase Innovations } \\
\text { - Improve Operational Capabilities } \\
\text { - Improve Operational Efficiency }\end{array}$ & $\begin{array}{l}\text { - Productivity Growth } \\
\text { - Growth of Banking Services } \\
\text { - Credit Growth } \\
\text { - Growth in Software Applications } \\
\text { - Front Office Employees }\end{array}$ & $\begin{array}{l}125 \% \\
20 \% \\
400 \% \\
70 \% \\
3 \%\end{array}$ \\
\hline 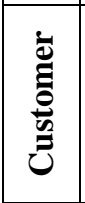 & $\begin{array}{l}\text { - Customer Retention } \\
\text { - Attract New Customers } \\
\text { - Increase Market Share }\end{array}$ & $\begin{array}{l}\text { - Customer Satisfaction, } \\
\text { - Customers' Growth } \\
\text { - Growth of Current Accounts } \\
\text { - Growth of Saving Accounts } \\
\text { - Growth of Safety Deposits. }\end{array}$ & $\begin{array}{l}1.5 \% \\
100 \% \\
180 \% \\
50 \% \\
100 \%\end{array}$ \\
\hline 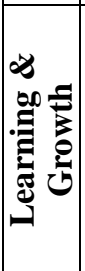 & $\begin{array}{l}\text { - Improve Employees Capabilities } \\
\text { - Improve Employee Satisfaction } \\
\text { - Improve Computerized System } \\
\text { Application }\end{array}$ & $\begin{array}{l}\text { - Employee Productivity } \\
\text { - Employee Turnover } \\
\text { - Growth of the Bank's Branches } \\
\text { - Employee Participation in Development } \\
\text { Programs } \\
\text { - Number of Employees Using IT in their } \\
\text { work. }\end{array}$ & $\begin{array}{l}\$ 10000-\$ 35000 \\
1 \%-5 \% \\
100 \% \\
40-80 \text { programs } \\
400-1400 \\
\text { employees }\end{array}$ \\
\hline
\end{tabular}


Table 2. Balanced scorecard of the LLB

\begin{tabular}{|c|c|c|c|c|c|c|c|c|c|c|}
\hline & \multirow{3}{*}{ Measures } & \multicolumn{5}{|c|}{ Scores } & \multicolumn{4}{|c|}{ Score Assignment } \\
\hline & & 10 & 20 & 30 & 40 & 50 & \multirow{2}{*}{2006} & \multirow{2}{*}{2007} & \multirow{2}{*}{2008} & \multirow{2}{*}{2009} \\
\hline & & & & Scale & & & & & & \\
\hline \multirow{6}{*}{ 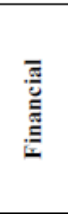 } & \begin{tabular}{|l|} 
Liquidity Ratio \\
\end{tabular} & $1-6 \%$ & $7-12 \%$ & $13-18 \%$ & $19-24 \%$ & $25-30 \%$ & 50 & 50 & 50 & 50 \\
\hline & ROI & $1-3 \%$ & $4-6 \%$ & $7-9 \%$ & $10-12 \%$ & $13-15 \%$ & 10 & 10 & 10 & 50 \\
\hline & ROE & $1-80 \%$ & $81-160 \%$ & $161-240 \%$ & $241-320 \%$ & $321-400 \%$ & 10 & 20 & 50 & 50 \\
\hline & Profit Margin & $1-40 \mathrm{~m}$ & $41-80 \mathrm{~m}$ & $81-120 \mathrm{~m}$ & $121-160 \mathrm{~m}$ & $161-200 \mathrm{~m}$ & 10 & 10 & 50 & 50 \\
\hline & Leverage Ratio & $100-130 \%$ & $\begin{array}{c}131- \\
160 \%\end{array}$ & $161-190 \%$ & $191-220 \%$ & $221-250 \%$ & 20 & 20 & 40 & 50 \\
\hline & \multicolumn{6}{|l|}{ Perspective Subtotal / year } & 100 & 110 & 200 & 250 \\
\hline \multirow{6}{*}{ 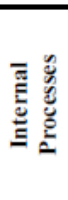 } & Productivity Growth & $1-25 \%$ & $26-50 \%$ & $51-75 \%$ & $76-100 \%$ & $101-125 \%$ & 0 & 20 & 50 & 20 \\
\hline & Growth of Banking Services & $1-4 \%$ & \multirow{2}{*}{$\begin{array}{c}5-8 \% \\
81-160 \%\end{array}$} & $9-12 \%$ & $13-16 \%$ & $17-20 \%$ & 50 & 40 & 0 & 0 \\
\hline & \begin{tabular}{|l} 
Credit Growth \\
\end{tabular} & $1-80 \%$ & & $161-240 \%$ & $241-320 \%$ & $321-400 \%$ & 0 & 50 & 0 & 50 \\
\hline & Growth in Software Applications & $1-14 \%$ & $15-28 \%$ & $29-42 \%$ & $43-56 \%$ & $57-70 \%$ & 50 & 20 & 0 & 10 \\
\hline & Front Office Employees & $0.1-0.6 \%$ & $0.7-1.2 \%$ & $1.3-1.8 \%$ & $1.9-2.3 \%$ & $2.4 .3 \%$ & 50 & 20 & 10 & 20 \\
\hline & \multicolumn{6}{|l|}{ Perspective Subtotal /year } & 150 & 150 & 60 & 100 \\
\hline \multirow{6}{*}{ 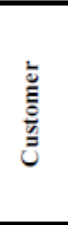 } & Customer Satisfaction, & $0.1-0.3 \%$ & $0.4-0.6 \%$ & $0.7-0.9 \%$ & $1-1.2 \%$ & $1.3-1.5 \%$ & 50 & 20 & 30 & 30 \\
\hline & Customers' Growth & $1-20 \%$ & $21-40 \%$ & $41-60 \%$ & $61-80 \%$ & $81-100 \%$ & 0 & 0 & 0 & 0 \\
\hline & Growth of Current Accounts & $1-35 \%$ & $36-71 \%$ & $72-108 \%$ & $109-143 \%$ & $144-180 \%$ & 50 & 10 & 20 & 10 \\
\hline & Growth of Saving Accounts & $1-10 \%$ & $11-20 \%$ & $21-30 \%$ & $31-40 \%$ & $41-50 \%$ & 10 & 30 & 10 & 50 \\
\hline & Growth of Safety Deposits & $1-20 \%$ & $21-40 \%$ & $41-60 \%$ & $61-80 \%$ & $81-100 \%$ & 0 & 0 & 50 & 20 \\
\hline & \multicolumn{6}{|l|}{ Perspective Subtotal/year } & 110 & 60 & 110 & 110 \\
\hline \multirow{7}{*}{ 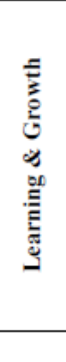 } & Employee Productivity & $\$ 10000-15000$ & $\$ 15001-20000$ & $\$ 20001-25000$ & $\$ 25001-30000$ & $\$ 30001-35000$ & 10 & 30 & 10 & 20 \\
\hline & Employee Turnover & $0.1-1 \%$ & $1.1-2 \%$ & $2.1-3 \%$ & $3.14 \%$ & $4.1-5 \%$ & 40 & 30 & 30 & 30 \\
\hline & Growth of the Bank's Branches & $0.1-2 \%$ & $2.14 \%$ & $4.1-6 \%$ & $6.1-8 \%$ & $8.1-10 \%$ & 0 & 0 & 0 & 0 \\
\hline & $\begin{array}{l}\text { Employee Participation in } \\
\text { Development Programs }\end{array}$ & 41.48 & $49-56$ & $57-64$ & $65-72$ & $73-80$ & 50 & 30 & 10 & 20 \\
\hline & $\begin{array}{l}\text { Number of Employees Using IT } \\
\text { in their work. }\end{array}$ & $400-600$ & $601-800$ & $801-1000$ & $1001-1200$ & $1201-1400$ & 10 & 20 & 50 & 50 \\
\hline & \multicolumn{6}{|l|}{ Perspective Subtotal/year } & 110 & 110 & 100 & 120 \\
\hline & \multicolumn{6}{|l|}{ Total Scores on four perspectives } & 470 & 430 & 470 & 580 \\
\hline
\end{tabular}

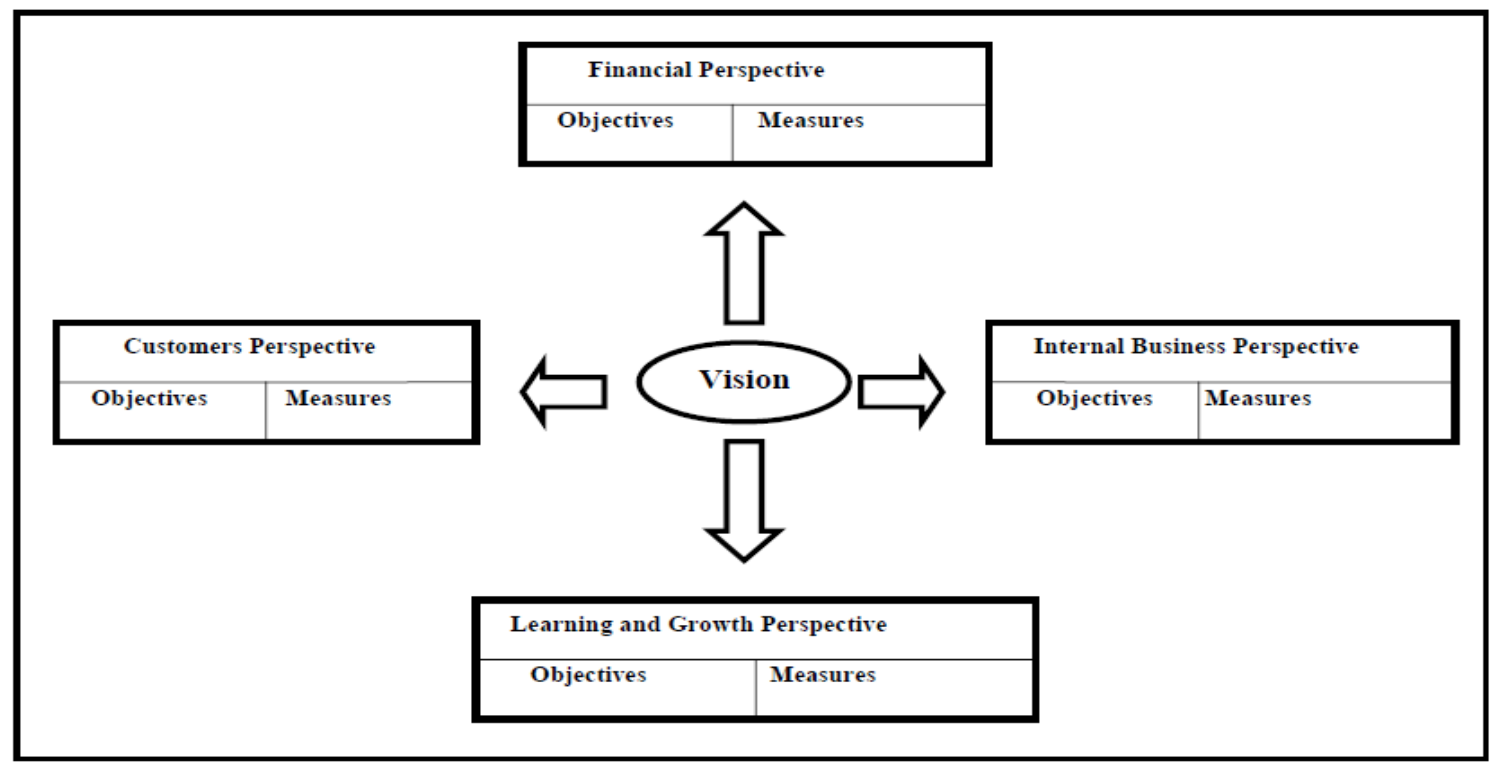

Figure 1. Balanced scorecard perspectives

Kaplan \& Norton, 1992. 


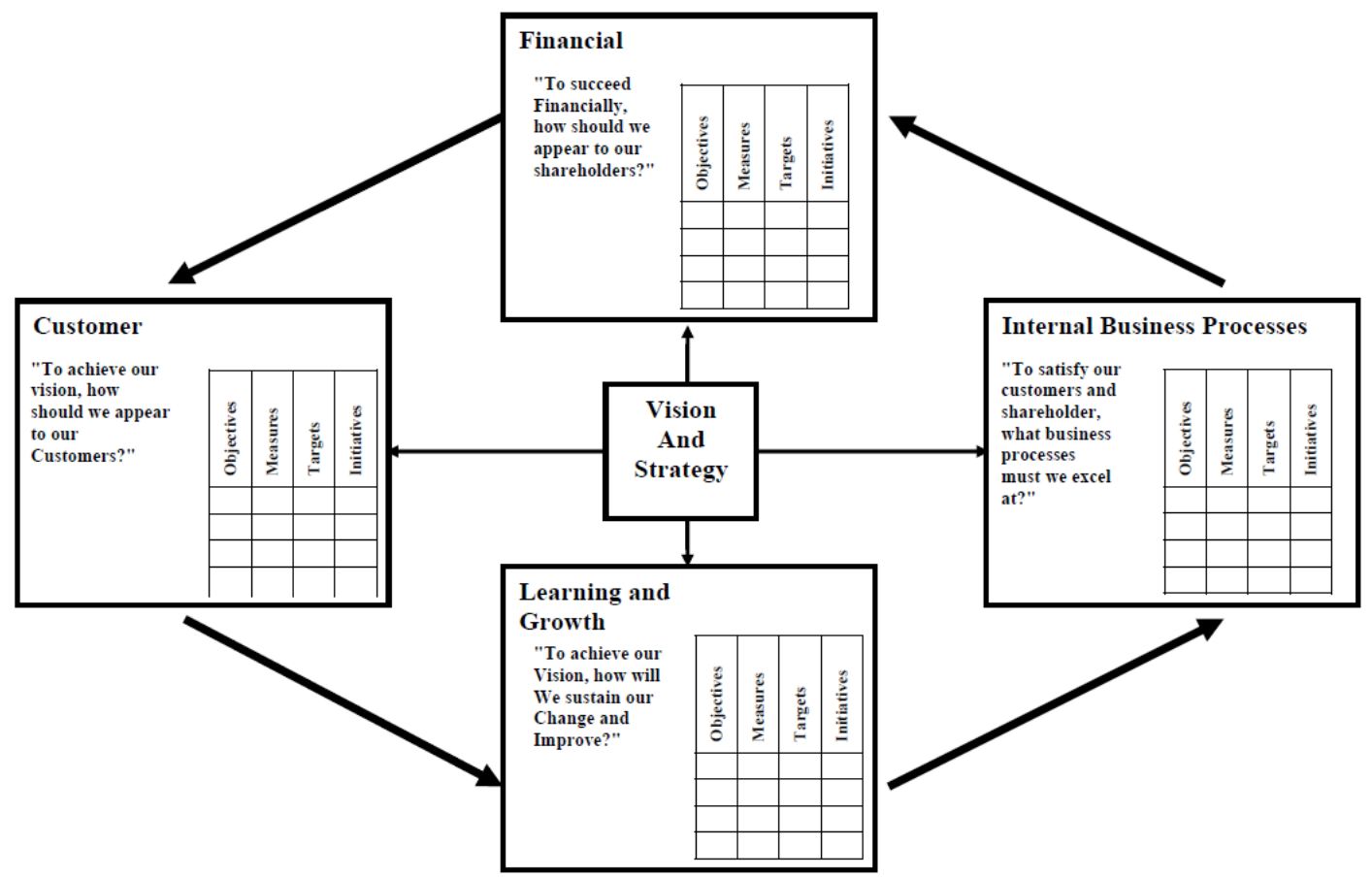

Kaplan \& Norton, 1996.

Figure 2. Balanced scorecard-second version

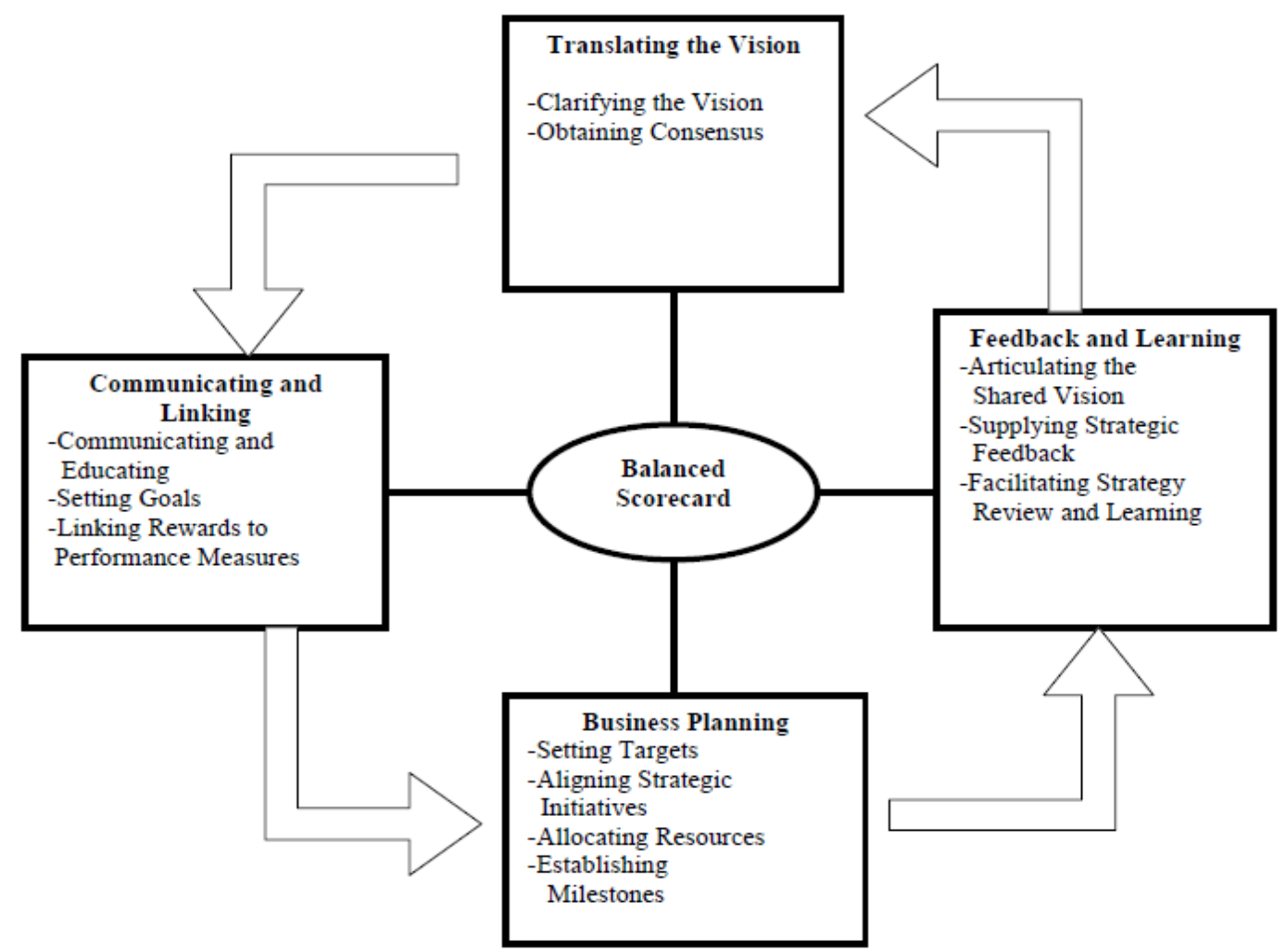

Source: Kaplan \& Norton, 1996.

Figure 3. Managing strategy: four processes 